Нестеров C.B.

\title{
К ВОПРОСУ О ФОРМАХ СОУЧАСТИЯ В ПРЕСТУПЛЕНИЯХ ПРОТИВ ОБЩЕСТВЕННОЙ БЕЗОПАСНОСТИ
}

\begin{abstract}
Аннотация: Институт фрорм соучастия безусловно является одним из наиболее сложных и дискуссионных. Одним из основных признаков в определении фрормы соучастия является степень согласованности действий соучастников, как при подготовке, так и при совершении конкретного преступления. Предметом исследования является совокупность объективных и субъективных признаков соучастия, характеризующих совместность деяний соучастников, отражающая степень согласованности действий их соучастников при подготовке или при совершении преступления и степень общественной опасности самого преступления (преступлений). Авторами были использованы следующие методологические основы: совокупность общенаучных и специальных методов познания социально-правовой действительности. Для фрормулирования правильных выводов о фоормах соучастия в преступлениях против общественной безопасности авторами разработаны предложения по наполнению уголовного закона соответствующей терминологией. Были разработаны авторские понятия: общественной безопасности, соучастия и фрормы соучастия в преступлении, преступного и террористического сообщества, заказчика преступления как одного из соучастников. Разработаны предложения по совершенствованию законодательства, которые будут способствовать противодействию преступлениям против общественной безопасности, совершаемым в соучастии.
\end{abstract}

Ключевые слова: Соучастие в преступлении, форма соучастия, классификация соучастия, преступность, уголовное право, общественная безопасность, преступное сообщество, террористическое сообщество, корректировка законадательства, правопорядок.

Review: The problem of forms of criminal participation is one of the most difficult and disputable. One of the main features, helping identify the form of criminal participation, is the level of uniformity of action of accomplices in preparing and committing the crime. The research subject is the set of objective and subjective features of criminal participation, characterizing the simultaneity of actions of accomplices, reflecting the level of uniformity of their actions in preparing and committing the crime and the level of public danger of the crime. The author applies the set of general scientific and special methods of cognition of the socio-legal reality. To formulate the correct conclusions about the forms of participation in crimes against public order, the author develops the proposals about amending the legislation with the required terminology. The author develops the terms of public danger, criminal participation and forms of criminal participation, criminal and terrorist group and a killing organizer as one of the accomplices. The author offers the ways of the legislation improvement which will promote the prevention of crimes against public safety committed in accompliceship.

Keywords: Criminal group, public safety, criminal law, crime, accompliceship classification, form of participation, criminal participation, terrorist group, legislation adjustment, law and order.

П роблемы обеспечения общественной безопасности органически связаны с политическими, экономическими, социальными, государственно-правовыми реформами, проблемами формирования правового государства, гражданского общества и демократии. Государство не всегда способно эффрективно противостоять новым современным террористическим угрозам, которые становятся, к сожалению, устойчивым фрактором, дестабилизирующим процессы многих стран.

Как отмечалось на прошедшем 31.03.2015 г. Координационном совеща- 
нии руководителей правоохранительных органов Российской Федерации, особую опасность вызывает связь бандподполья с международными террористическими организациями и участие граждан России в вооруженном конфликте на территории Сирийской Арабской Республики.

Реформирование антитеррористического законодательства идет, но внесение в УК РФ новых статей - 205.4 и 205.5 о террористической организации и террористическом сообществе оцениваются учеными как заслуживающие преимущественно критических оценок.

Сказанное свидетельствует о высокой вероятности возникновения социально опасных ситуаций, которые, оказывая разрушительное воздействие на сложившуюся систему общественных отношений, культурно-исторические традиции и обычаи, обусловливают нарастание степени риска для жизнедеятельности каждого человека, а также угрозы национальным и международным интересам. Социальная потребность в научно-практической разработке проблем уголовно-правового обеспечения общественной безопасности в Российской Федерации вызвана еще и тем, что формирование современных теоретических и законодательных ее основ имеет весьма непродолжительную историю.

Серьезным испытанием для общественной безопасности является деятельность незаконных вооруженных фрормирований и преступных сообществ (преступных организаций). Уголовная ответственность за создание и руководство незаконными вооруженными формированиями и преступными сообществами была установлена УК РФ. Бандитизм, являющийся прообразом указанных выше преступлений, был знаком российскому законодательству много раньше. Преступления, указанные в ст. ст. 205.4, 205.5, 208, 209, 210 УК РФ, послужили основой анализа института сложных форм соучастия, как в российском, так и в зарубежном уголовном законодательстве.

Прослеживается следующая динамика бандитизма: в 2012 году - 236, в 2013 г. 233 , в 2014 году - 182, что на 21,9\% меньше чем в предыдущие годы. В 2013 году зарегистрирован 251 факт организации преступного сообщества (преступной организации), а в 2014 - уже 255. С введением новых статей в уголовный кодекс - ст. 205.4 «Организация террористического сообщества и участие в нем», в 2014 году было зарегистрировано 9 таких преступлений, а по ст. 205.5 УК РФ «Организация деятельности террористической организации и участие в деятельности такой организации» - 30 .

Организованными группами (преступными сообществами) в 2013 году совершено 16,6 тыс. тяжких и особо тяжких преступлений $(-4,3 \%)$, в 2014 году наметился спад количества преступлений, выраженных в абсолютных величинах это 13659 преступлений, в 2015 году из общего числа выявленных лиц, совершивших преступление в составе группы - 152072 (без учета Крымского ФО - 150332), по сравнению с 2014 годом прирост 9,1\%. В 2014 году было раскрыто четырнадцать тысяч преступлений, совершенных организованными группами или преступными сообществами, выявлено 178 преступлений, связанных с организацией преступного сообщества, пресечена деятельность почти восьми с половиной тысяч лидеров и активных участников организованных групп, к уголовной ответственности привлечено 36 криминальных «авторитетов».

Для формулирования правильных выводов о формах соучастия в преступлениях против общественной безопасности необходимо определиться терминологией. Предлагаем под общественной безопасностью понимать состояние защищенности общества от угроз неправового характера, позволяющее ему сохранять качественную определенность и способствующее его устойчивому развитию. Формой соучастия признать - совокупность объективных и субъективных признаков соучастия, характеризующих совместность деяний соучастников, отражающая степень согласованности их действий при подготовке или при совершении преступления и степень общественной опасности самого преступления (преступлений).

При этом надо учитывать, что нет отличия в формах соучастия у террористи- 


\section{Полиция и проблемы противодействия терроризму и экстремизму}

ческой организации (ст. 205.5 УК РФ) и террористического сообщества (ст. 205.4 УК РФ), фрормально оно заключается лишь в наличии вступившего в законную силу решения суда о признании организации террористической либо обвинительного приговора суда в отношении лица за создание, руководство или участие в террористическом сообществе.

Под террористическим сообществом (ст. 205.4 УК РФ) следует понимать устойчивую группу лиц, заранее объединившихся для подготовки или совершения террористической деятельности либо для подготовки или совершения одного либо нескольких преступлений, предусмотренных ст. ст. 205.1, 205.2, 206, 208, 211, 220, 221 , 277, 278, 279 и 360 УК РФ, характеризующуюся наличием в ее составе организатора (руководителя), стабильностью состава, согласованностью действий ее участников в целях реализации общих преступных намерений.

В диспозиции ч.1 ст. 205.4 УК РФ употреблён термин «подготовка», который в уголовном кодексе не раскрыт, и, согласно буквальному толкованию совпадает с понятие «приготовление», описанным в ст. 30 УК РФ. Употребление новых терминов для имеющихся уголовно-правовых понятий нарушает правила законодательной техники, поэтому, для устранения сложностей при квалификации деяний, необходимо в диспозиции ч. 1 ст. 205.4 УК РФ термин «подготовка» изменить на «приготовление».

Соучастием в преступлении, на наш взгляд является умышленное совместное участие двух или более лиц в совершении умышленного или неосторожного преступления, а организованной группой - устойчивая группа лиц в количестве не менее трех человек, заранее объединившихся для совершения умышленных преступлений, имеющей руководителя, распределившего роли.

Преступным сообществом является - устойчивая, структурированная организованная группа или объединение организованных групп, действующих под единым руководством, члены которых дисциплини- рованы, законспирированы, объединены в целях совместного совершения одного или нескольких тяжких либо особо тяжких преступлений для получения прямо или косвенно материальной выгоды, имеющая фринансовую базу, оружие, возможно коррупционные связи.

А террористическим сообществом устойчивая, стабильная, структурированная организованная группа лиц или объединение организованных групп под единым руководством, заранее объединившихся и действующих согласованно в целях осуществления террористической деятельности либо для подготовки или совершения одного либо нескольких преступлений, предусмотренных ст. ст. 205.1, 205.2, 206, $211,220,221,277,278,279$ и 360 УК РФ, либо иных преступлений в целях пропаганды, оправдания и поддержки терроризма.

Анализ показал, что уголовно-правовая норма, указанная в ч. 4 ст. 210 УК РФ не используется правоприменителем, не имеет научного и легального толкования, поэтому оправданным будет отменить признак «лицо, занимающее высшее положение в преступной иерархии». С целью уточнения ролей соучастников установлено, что определение подстрекателя, данное в УК РФ, устарело, а термин «заказчик преступления» получил свое самостоятельное значение, в науке и следственной практике. Предложено выделить его в качестве соучастника в ч. 6 ст. 33 УК и дать следующее определение: «Заказчиком преступления признается лицо, оплатившее (оказавшее услугу) в любой форме другому лицу (лицам) исполнение преступления, предусмотренного настоящим Кодексом» .

Ч. 1 ст. 208 УК РФ необходимо изложить в следующей редакции: «1. Создание, либо фринансирование незаконного вооруженного фрормирования (объединения, отряда, дружины или иной организованной группы), имеющего структуру, управление и иерархию, а равно руководство таким формированием с целью использования участников незаконного вооруженного формирования для совершения преступлений и вооруженного столкновения с законно действующими силовыми структурами». 
Согласно принципу справедливости, считаем, что следует запретить виновным, совершившим преступление, предусмотренное ч. ч. 1 и 2 ст. 209 УК - «с использованием своего служебного положения», занимать в дальнейшем должности в государственных учреждениях на максимально возможный срок - 20 лет, возможна следующая редакция ч. 3 ст. 209 УК РФ: «3. Деяния, предусмотренные частями первой или второй настоящей статьи, совершенные лицом с использованием своего служебного положения,

- наказываются лишением свободы на срок от двенадцати до двадцати лет со штрафом в размере до одного миллиона рублей или в размере заработной платы или иного дохода, осужденного за период до пяти лет либо без такового и с лишением права занимать должности на государственной службе, в органах местного самоуправления до двадцати лет».

Статьи 208 и 209 УК РФ нуждаются в объединении: «1. Создание, а равно руководство незаконными вооруженными формированиями либо устойчивыми вооруженными организованными группами (бандами) с целью посягательств на законные интересы личности, общества или государства,

- наказывается лишением свободы на срок от восьми до пятнадцати лет со штрафом до одного миллиона рублей или в размере заработной платы или иного дохода, осужденного за период до пяти лет либо без такового и с ограничением свободы на срок от одного года до двух лет.
2. Активное участие в деятельности незаконных вооруженных формирований либо устойчивых вооруженных организованных групп (банд), а равно их финансирование.

- наказывается лишением свободы на срок от пяти до десяти лет со штрафом до одного миллиона рублей или в размере заработной платы или иного дохода, осужденного за период до пяти лет либо без такового и с ограничением свободы на срок от одного года до двух лет.

3. Участие в деятельности незаконных вооруженных формирований либо устойчивых вооруженных организованных групп (банд),

- наказывается лишением свободы на срок от трех до семи лет с ограничением свободы на срок от одного года до двух лет.

4. Создание либо участие в деятельности незаконных вооруженных формирований, либо устойчивых вооруженных организованных групп (банд), совершенные лицом с использованием своего служебного положения,

- наказываются лишением свободы на срок от двенадцати до двадцати лет со штрафом в размере до одного миллиона рублей или в размере заработной платы или иного дохода, осужденного за период до пяти лет либо без такового и с лишением права занимать должности на государственной службе, в органах местного самоуправления на двадцать лет».

Указанные предложения будут способствовать противодействию преступлениям против общественной безопасности, совершаемым в соучастии.

\section{Библиография:}

1. Пудовочкин Ю.Е. Судебная практика квалификации преступлений, совершенных в соучастии Криминологический журнал Байкальского государственного университета экономики и права. 2011. № 2. С. 5-15.

2. Гаухман Л.Д. Квалификация преступлений: закон, теория, практика. 4-е изд., перераб. и доп. М.: АО «Центр «ЮрИнфроР», 2010. 198 с.

3. Виденькина Ж.В. Ответственность за организацию преступного сообщества или участие в нем: научно-практическое пособие / Отв. ред. Н.Г. Кадников. М.: Юриспруденция, 2014. 136 с.

4. Безниско М.О. Соучастие в преступлении // Гуманитарные и социальные науки. 2013. № 6. C. 245.

5. Жалинский А.Э. Криминологическая характеристика терроризма в России // Национальная безопасность / nota bene. - 2012. - 2. - С. 22 - 29. 


\section{Полиция и проблемы противодействия терроризму и экстремизму}

\section{References (transliterated):}

1. Pudovochkin Yu.E. Sudebnaya praktika kvalifikatsii prestuplenii, sovershennykh v souchastii Kriminologicheskii zhurnal Baikal'skogo gosudarstvennogo universiteta ekonomiki i prava. 2011. № 2. S. 5-15.

2. Gaukhman L.D. Kvalifikatsiya prestuplenii: zakon, teoriya, praktika. 4-e izd., pererab. i dop. M.: AO "Tsentr "YurlnfoR", 2010. 198 s.

3. Viden'kina Zh.V. Otvetstvennost' za organizatsiyu prestupnogo soobshchestva ili uchastie $v$ nem: nauchno-prakticheskoe posobie / Otv. red. N.G. Kadnikov. M.: Yurisprudentsiya, 2014. $136 \mathrm{~s}$.

4. Beznisko M.O. Souchastie v prestuplenii // Gumanitarnye i sotsial'nye nauki. 2013. № 6. S. 245.

5. Zhalinskii A.E. Kriminologicheskaya kharakteristika terrorizma v Rossii // Natsional'naya bezopasnost' / nota bene. - 2012. - 2. - C. $22-29$. 